\title{
Pengaruh Pelayanan dan Fasilitas terhadap Kepuasan Mahasiswa Sekolah Tinggi Agama Buddha Negeri Sriwijaya Tangeran Banten
}

\author{
Heriyanto \\ Sekolah Tinggi Agama Buddha Negeri Sriwijaya Tangerang Banten \\ heriyanto@stabn-sriwijaya.ac.id
}

\begin{abstract}
Abstrak
Masalah dalam penelitian ini adalah belum diketahuinya pengaruh Pelayanan dan Fasilitas terhadap Kepuasan Mahasiswa STABN Sriwijaya. Tujuan penelitian adalah untuk mengetahui pengaruh Pelayanan dan Fasilitas terhadap kepuasan mahasiswa STABN Sriwijaya. Penelitian dibatasi pada mahasiswa STABN Sriwijaya semester genap tahun akademik 2014/2015.

Jenis penelitian kuantitatif dengan pendekatan Ex Post Facto. Penelitian ini merupakan penelitian populasi. Penelitian dilakukan di STABN Sriwijaya Tangerang Banten. Subjek penelitian adalah mahasiswa STABN Sriwijaya tahun akademik 2014/2015 berjumlah 116 orang. Objek penelitian terdiri dari Pelayanan, Fasilitas, dan Kepuasan Mahasiswa STABN Sriwijaya. Variabel independen penelitian yaitu Pelayanan $\left(X_{1}\right)$ dan Fasilitas $\left(X_{2}\right)$, sedangkan variabel dependen pada penelitian yaitu Kepuasan Mahasiswa STABN Sriwijaya (Y). Pengumpulan data dilakukan dengan teknik non-tes menggunakan kuesioner dengan lima klasifikasi menggunakan skala Likert. Kuesioner yang dibagikan berjumlah 116, dua tidak dikembalikan dengan alasan yang tidak diketahui. Pengujian asumsi klasik dilakukan dengan uji normalitas regresi, multikolinearitas, heteroskedastisitas, dan uji autokorelasi. Uji prasyarat dilakukan dengan uji validitas dan uji reliabilitas. Teknik analisis data yang digunakan dalam penelitian ini adalah analisis Regresi Linier Berganda.
\end{abstract}

Hasil penelitian mendapatkan persamaan Regresi Linier Berganda. Nilai persamaan Regresi Linier Berganda adalah $Y^{\prime}=(-0,225)+0,495 X_{1}+0,691 X_{2}$. Terjadi hubungan positif antara Pelayanan dan Fasilitas terhadap Kepuasan Mahasiswa. Kenaikan Pelayanan dan Fasilitas akan diikuti dengan peningkatan Kepuasan Mahasiswa STABN Sriwijaya. Penurunan Pelayanan dan Fasilitas akan diikuti juga dengan menurunnya tingkat kepuasan Mahasiswa STABN Sriwijaya. Terdapat pengaruh antara Pelayanan dan Fasilitas secara bersama-sama terhadap Kepuasan Mahasiswa STABN Sriwijaya sebesar 73,4\%. Secara parsial terdapat pengaruh Pelayanan terhadap Kepuasan Mahasiswa STABN Sriwijaya dan terdapat pengaruh signifikan Fasilitas terhadap Kepuasan Mahasiswa STABN Sriwijaya.

\section{A. Pendahuluan}

Berbagai institusi dalam menjalankan proses bisnis utama haruslah searah dan mempertimbangkan relevansi proses dengan berbagai kebutuhan. Dalam 
bidang pendidikan, perguruan tinggi harus terus mengamati kebutuhan mahasiswa sehingga dapat mengantisipasi perubahan dalam menciptakan sebuah kajian strategi, manajemen, dan kebijakan. Untuk selanjutnya dapat diterapkan dalam rangka peningkatan pelayanan jasa pendidikan yang dilakukan. Keberhasilan perguruan tinggi dapat diukur melalui indikator tingkat kepuasan mahasiswa terhadap proses pendidikan yang dilakukan. Kepuasan mahasiswa terbentuk dengan adanya persepsi positif dan negatif terhadap proses akademik. Kepuasan mahasiswa menggambarkan tingkat harapan dengan kenyataan yang diterima kaitannya dengan proses akademik pada sebuah perguruan tinggi.

Perguruan tinggi dituntut untuk mengidentifikasi para mahasiswa beserta kebutuhannya untuk menciptakan sebuah kepuasan. Kenyataan masih banyaknya tingkat kepuasan mahasiswa yang rendah pada perguruan tinggi. Ketidakpuasan terhadap proses pembelajaran, pelayanan administrasi yang tidak tepat waktu, tidak responsif terhadap keluhan mahasiswa, fasilitas yang tidak lengkap, kebijakan kampus yang kurang menyentuh ranah kebutuhan mahasiswa, kurikulum yang kurang up to date, dan kompetensi dosen yang dirasa kurang menjadi potret umum yang berakibat pada rendahnya tingkat kepuasan mahasiswa. Berbagai permasalahan tingkat kepuasan mahasiswa dikelompokkan ke dalam beberapa dimensi, seperti: pelayanan, fasilitas, kebijakan, dan kepemimpinan.

Pelayanan yang baik sebuah keharusan agar mahasiswa merasa puas dengan apa yang mereka dapatkan. Pelayanan yang baik membentuk persepsi positif pada masing-masing individu mahasiswa. Persepsi akan diikuti dengan berbagai tindakan penghargaan dan merekomendasikan perguruan tinggi tersebut yang akan berdampak pada keberlangsungan dan daya kompetitif perguruan tinggi sekarang maupun akan datang.

Berangkat dari pentingnya pelayanan, masih terdapat mahasiswa pada beberapa perguruan tinggi mengeluhkan pelayanan yang didapatkan dirasa sangat kurang. Operasional hanya dijalankan tanpa perubahan kebijakan dan penerepan manajemen yang handal untuk menjadi lebih relevan terhadap kebutuhan. Penilaian negatif muncul dikarenakan pelayanan administrasi akademik yang kurang baik dan daya tanggap lemah terhadap keluhan mahasiswa. Bentuk lainnya adalah banyaknya kritikan terhadap kegiatan dan proses akademik pada perguruan tinggi.

Operasional akademik erat kaitannya dengan fasilitas yang ada pada sebuah perguruan tinggi. Dukungan fasilitas memberikan kontribusi besar terhadap operasional yang dilakukan. Fasilitas lengkap membantu dalam kegiatan akademik dan proses pembelajaran akan semakin mudah dengan fasilitas lengkap pada perguruan tinggi. Akses internet, komputer, LCD Proyektor, beasiswa, gedung kuliah, dan sarana olahraga merupakan bentuk-bentuk fasilitas yang memberikan kontribusi terhadap kegiatan mahasiswa. Fasilitas merupakan bentuk tangibles yang dirasakan langsung oleh mahasiswa erat 
kaitannya dengan tingkat kepuasan dalam sebuah manajemen kualitas dan pelayanan perguruan tinggi.

Kelengkapan fasilitas pendukung proses akademik pada perguruan tinggi tidak selalu berada pada taraf maksimal. Keyataan pada beberapa perguruan tinggi masih ditemukan minimnya fasilitas, baik dari sarana prasarana maupun program-program pendukung kegiatan akademik. Mahasiswa merasa bahwa kebutuhan akademik mereka kurang terfasilitasi pada kampus tempat menempuh pendidikan. Perguruan tinggi harus dikelola dengan berpedoman pada kepentingan sivitas akademika dan tenaga kependidikan. Berbagai permasalahan fasilitas berdampak pada terbentuknya perasaan tidak puas mahasiswa terhadap kampus dalam menjalankan jasa pendidikan yang dilakukan.

Perubahan paradigma perguruan tinggi di Indonesia yang lebih berfokus pada pelayanan mahasiswa menjadi dasar pentingnya dilakukan pengukuran kepuasan mahasiswa. Sekolah Tinggi Agama Buddha Negeri Sriwijaya (STABN Sriwijaya) merupakan perguruan tinggi negeri yang juga menghadapi tantangan yang sama. Bagaimana tingkat kepuasan mahasiswa dalam menempuh pendidikan di STABN Sriwijaya menjadi input penting dalam merumuskan berbagai kebijakan dan strategi yang akan dilakukan. Belum diketahuinya pengaruh pelayanan dan fasilitas terhadap Kepuasan Mahasiswa STABN Sriwijaya menjadi permasalahan tersendiri dalam penelitian ini. Berdasarkan latar belakang di atas peneliti bermaksud melakukan penelitian dengan judul "Pengaruh Pelayanan dan Fasilitas terhadap Kepuasan Mahasiswa Sekolah Tinggi Agama Buddha Negeri Sriwijaya Tangerang Banten". Tujuan penelitian adalah untuk mengatahui pengaruh pelayanan dan fasilitas terhadap kepuasan mahasiswa STABN Sriwijaya. Penelitian dibatasi pada mahasiswa STABN Sriwijaya semester genap tahun akademik 2014/2015.

\section{B. Konsep Teoretis}

\section{Pelayanan pada Perguruan Tinggi}

Pelayanan berasal dari kata service yang berarti melayani. Pelayanan merupakan setiap tindakan atau kegiatan yang dapat ditawarkan oleh suatu pihak kepada pihak lain, pada dasarnya tidak berwujud dan tidak mengakibatkan kepemilikan apapun (Kotler, 2012: 356). Berkaitan dengan jasa yang diberikan, pelayanan merupakan proses melayani pengguna jasa yang ditawarkan sehingga memberikan kesan dan persepsi positif kepada pengguna jasa. Pelayanan pada perguruan tinggi merupakan berbagai bentuk layanan yang dilakukan seluruh sumber daya pegawai dalam membentuk penyelenggaraan operasional dan kegiatan akademik. Kualitas pelayanan yang diterima konsumen dinyatakan dengan besarnya perbedaan antara harapan atau keinginan konsumen dengan tingkat persepsi mereka (Ratnasari dan Mastuti, 2011: 107). Kualitas pelayanan jasa adalah tingkat keunggulan yang diharapkan dan pengendalian atas tingkat 
keunggulan tersebut untuk memenuhi keinginan pelanggan (Tjiptono, 2014: 59). Kualitas pelayanan pada perguruan tinggi merupakan perbandingan harapan mahasiswa dengan kinerja perguruan tinggi berkaitan dengan layanan akademik yang diberikan. Pelayanan yang dirasakan oleh mahasiswa dalam hal ini penerima jasa pendidikan pada akhirnya dapat menentukan tingkat kepuasan (customer satisfaction).

Parasuraman, Zeithaml, dan Berry (dalam Tjiptono, 2011: 69) mendefinisikan lima dimensi kualitas layanan yaitu: 1) Bukti fisik (tangibles), 2) Kehandalan (reliability), 3) Daya tanggap (responsiveness), 4) Jaminan (assurance), dan 5) Empati (empathy). Secara spesifik Kotler dan Fox (dalam Abdullah, Sukirno, Annisa, dkk, 2013: 102) mengemukakan terdapat enam dimensi utama kualitas pelayanan pada perguruan tinggi, yaitu: quality of instruction, academic advising, library resources, extracurricular activity opportunities to talk with faculty members, job placement services.

\section{Fasilitas pada Perguruan Tinggi}

Fasilitas merupakan segala sesuatu yang disediakan oleh penyedia jasa untuk dipakai serta dinikmati oleh konsumen yang bertujuan memberikan tingkat kepuasan maksimal. Fasilitas merupakan penampilan, kemampuan sarana prasarana dan keadaan lingkungan sekitarnya dalam menunjukkan eksistensinya kepada eksternal yang meliputi fasilitas fisik (gedung), perlengkapan, dan peralatan. Fasilitas dapat berupa alat, benda-benda, perlengkapan, uang, dan juga ruang tempat kerja (Lupiyoadi, 2013: 148). Dalam usaha yang bergerak di bidang jasa, maka segala fasilitas yang ada yaitu kondisi fasilitas, kelengkapan, desain interior dan eksterior, serta kebersihan fasilitas harus diperhatikan, terutama yang berkaitan erat dengan apa yang dirasakan atau didapat konsumen secara langsung.

Fasilitas pendidikan pada perguruan tinggi merupakan bentuk dukungan terhadap terlaksananya proses layanan akademik. Fasilitas dalam dunia pendidikan berarti segala sesuatu yang bersifat fisik maupun material, yang dapat memudahkan terselenggaranya proses pembelajaran, seperti tersedianya tempat pembelajaran, perlengkapan belajar di kelas, alat-alat peraga pembelajaran, buku pelajaran, perpustakaan, perlengkapan pratikum, dan kelengkapan laboratorium. Bentuk nyata fasilitas pada perguruan tinggi seperti: gedung kampus, ruang kelas, laboratorium, fasilitas internet, perpustakaan, kantin, peralatan dalam kelas yang dapat digunakan dalam proses pembelajaran. Dimensi fasilitas pada perguruan tinggi meliputi fleksibilitas, penataan, kualitas baik, kelayakan penggunaan, kelengkapan, sesuai kebutuhan, dukungan akademik, desain yang baik, kemudahan pengoperasian, dan ketersediaan sistem informasi (Tjiptono, Fandy, dkk, 2011: 180). 


\section{Kepuasan Mahasiswa}

Kepuasan adalah tingkat perasaan seseorang setelah membandingkan kinerja atau hasil yang dirasakannya dengan harapan yang dimiliki (Kotler dan Keller, 2012: 128). Apabila jasa yang didapat lebih kecil dari apa yang diharapkan, pelanggan menjadi tidak puas, tidak tertarik, dan kecewa kepada penyedia jasa. Sedangkan apabila jasa yang dirasa oleh pelanggan melebihi apa yang diharapkan maka pelanggan akan merasa puas. Tingkat kepuasan pelanggan dapat diperoleh setelah terjadinya tahap pembelian dan pemakaian (Kotler, 2009: 49). Dalam perguruan tinggi, kepuasan pelanggan berwujud sebagai kepuasan mahasiswa sebagai pengguna jasa pendidikan. Harapan selalu berada pada taraf yang ideal, perbedaan antara harapan dengan kenyataan yang diterima mahasiswa akan membentuk tingkat kepuasan pada diri masing-masing diri mahasiswa.

Kepuasan mahasiswa sebagai konsumen pendidikan dipengaruhi beberapa faktor, antara lain apresiasinya terhadap ilmu atau keterampilan yang diperoleh, pemahaman terhadap jalur karier yang akan dapat dimilikinya, pelayanan akademik, serta harapan-harapan atau ekspektasinya terhadap perguruan tinggi yang telah memberikan jasa pelayanan (services). Tingkat kepuasan mahasiswa dapat diukur melalui dimensi pelayanan perguruan tinggi. Kepuasan mahasiswa juga dapat dilihat melalui dimensi atau indikator quality of instruction, academic advising, library resources, extracurricular activity opportunities to talk with faculty members, job placement services".

Dimensi kepuasan mahasiswa dapat terlihat dari kepuasan terhadap proses akademik dan pembelajaran, bimbingan akademik, manajemen kampus, pelayanan administrasi, fasilitas dan sumber daya kampus, aktivitas ekstra kulikuler, aspek komunikasi pimpinan dan staf, pelayanan yang responsif, ketepatan dan keakuratan informasi, serta aspek kesopanan dan keramahan layanan administrasi akademik. Secara spesifik dimensi kepuasan mahasiswa terdiri dari: 1) puas terhadap proses pembelajaran, 2) puas terhadap manajemen akademik kampus, 3) puas terhadap pelayanan administrasi, 4) puas terhadap fasilitas kampus, 5) puas terhadap sarana prasaran pembelajaran, 6) puas terhadap komunikasi responsive, 7) puas terhadap layanan akademik, 8) puas terhadap kurikulum, 9) puas dengan kebijakan akademik kampus, dan 10) puas terhadap pengelolaan kampus.

\section{Metodologi Penelitian}

Jenis penelitian ini adalah penelitian kuantitatif dengan pendekatan ex post facto. Penelitian dilakukan pada STAB Negeri Sriwijaya Tangerang Banten. Subjek penelitian adalah mahasiswa STABN Sriwijaya tahun akademik 2014/2015. Objek penelitian terdiri dari pelayanan, fasilitas, dan kepuasan mahasiswa STABN Sriwijaya. Variabel penelitian terdiri dari dua variabel 
independen $(\mathrm{X})$ dan satu variabel dependen $(\mathrm{Y})$. Variabel independen penelitian yaitu Pelayanan $\left(X_{1}\right)$ dan Fasilitas $\left(X_{2}\right)$, sedangkan variabel dependen pada penelitian yaitu Kepuasan Mahasiswa STABN Sriwijaya kompetensi (Y).

Penelitian ini merupakan penelitian populasi. Populasi dalam penelitian adalah seluruh mahasiswa STABN Sriwijaya pada semester berjalan tahun akademik 2014/2015 yang berjumlah 116 orang. Pengumpulan data dilakukan dengan teknik non-tes menggunakan kuesioner dengan lima klasifikasi skala Likert. Kuesioner yang dibagikan berjumlah 116, dua tidak dikembalikan dengan alasan yang tidak diketahui. Pengujian asumsi klasik dilakukan dengan uji normalitas regresi, multikolinearitas, heteroskedastisitas, dan uji autokorelasi. Uji prasyarat dilakukan dengan uji validitas dan uji reliabilitas. Teknik analisis data yang digunakan dalam penelitian ini adalah analisis Regresi Linier Berganda.

\section{Validitas dan Reliabilitas Instrumen Penelitian}

Populasi penelitian berjumlah 114 orang, menggunakan rumus Slovin, didapatkan sampel penelitian berjumlah 89. Dengan demikian untuk uji coba instrumen penelitian dapat menggunakan 25 data yang diambil secara acak mewakili setiap semester dan jurusan dalam kelompok data mahasiswa STABN Sriwijaya Tangerang Banten.

Tabel 1. Validitas Instrumen Penelitian

\begin{tabular}{|l|c|c|c|c|c|c|c|c|c|c|}
\hline \multirow{2}{*}{ No. } & \multicolumn{4}{|c|}{ X1 } & \multicolumn{3}{|c|}{ X2 } & \multicolumn{3}{|c|}{ Y } \\
\cline { 2 - 12 } & $\begin{array}{c}\text { No. } \\
\text { Butir }\end{array}$ & $\begin{array}{c}\text { r. } \\
\text { hitung }\end{array}$ & Valid & $\begin{array}{c}\text { Tidak } \\
\text { Valid }\end{array}$ & $\begin{array}{c}\text { r. } \\
\text { hitung }\end{array}$ & Valid & $\begin{array}{c}\text { Tidak } \\
\text { Valid }\end{array}$ & $\begin{array}{c}\text { r. } \\
\text { hitung }\end{array}$ & Valid & $\begin{array}{c}\text { Tidak } \\
\text { Valid }\end{array}$ \\
\hline 1. & 1 & 0,321 & & $*$ & 0,481 & $*$ & & 0,745 & $*$ & \\
\hline 2. & 2 & 0.642 & $*$ & & 0.426 & $*$ & & 0.532 & $*$ & \\
\hline 3. & 3 & 0,642 & $*$ & & 0,379 & & $*$ & 0,748 & $*$ & \\
\hline 4. & 4 & 0,655 & $*$ & & - & & $*$ & 0,582 & $*$ & \\
\hline 5. & 5 & 0,818 & $*$ & & 0,671 & $*$ & & 0,490 & $*$ & \\
\hline 6. & 6 & 0,646 & $*$ & & 0,738 & $*$ & & 0,539 & $*$ & \\
\hline 7. & 7 & 0,595 & $*$ & & 0,123 & & $*$ & 0,584 & $*$ & \\
\hline 8. & 8 & 0,187 & & $*$ & 0,714 & $*$ & & 0,548 & $*$ & \\
\hline 9. & 9 & 0,581 & $*$ & & 0,411 & $*$ & & 0,442 & $*$ & \\
\hline 10. & 10 & 0,851 & $*$ & & 0,478 & $*$ & & 0,248 & & $*$ \\
\hline \multicolumn{2}{|r|}{ JUMLAH } & & 8 & 2 & & 7 & 3 & & 9 & 1 \\
\hline
\end{tabular}

Pengujian menggunakan uji dua sisi dengan taraf signifikansi 0,05. Kriteria pengujian jika $r$ hitung $\geq r$ tabel (uji 2 sisi dengan sig. 0,05) maka instrumen atau item-item pertanyaan berkorelasi signifikan terhadap skor total (dinyatakan valid), dan jika $r$ hitung $<\mathrm{r}$ tabel (uji 2 sisi dengan sig. 0,05) maka instrumen atau item-item pertanyaan tidak berkorelasi signifikan terhadap skor total (dinyatakan tidak valid). Nilai $\mathrm{r}$ tabel didapat dari tingkat kepercayaan (degree of freedom/ $d f$ ) yang merupakan jumlah responden dikurangi $2(25-2=23)$ dengan tingkat signifikansi 0,05 atau 5\%, maka nilai $\mathrm{r}$ tabel sebesar 0,3961. Dengan membandingkan hasil output corelated item total correlation dengan 0,3961, maka beberapa item instrumen penelitian dinyatakan tidak valid seperti terlihat pada tabel 1, untuk selanjutnya item yang tidak valid dikeluarkan dari data penelitian. 
Tabel 2. Reliabilitas Instrumen Penelitian

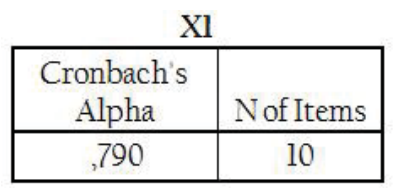

\begin{tabular}{|r|r|}
\hline \multicolumn{2}{|c|}{ X2 } \\
\begin{tabular}{|r|r|} 
Cronbach's \\
Alpha
\end{tabular} & $\begin{array}{c}\text { N of } \\
\text { Items }\end{array}$ \\
\hline, 598 & 10 \\
\hline
\end{tabular}

\begin{tabular}{|r|c|}
\hline $\begin{array}{c}\text { Cronbach's } \\
\text { Alpha }\end{array}$ & $\begin{array}{c}\text { N of } \\
\text { Items }\end{array}$ \\
\hline, 737 & 10 \\
\hline
\end{tabular}

Uji reliabilitas item dengan melihat koefisien alpha Cronbach. Jika alpha $>0,90$ maka reliabilitas sempurna, Jika alpha antara 0,70 - 0,90 maka reliabilitas tinggi, jika alpha antara 0,50 - 0,70 maka reliabilitas moderat, Jika alpha $<0,50$ maka reliabilitas rendah (Hilton dan Brownlow, 2004: 364). Tabel 2. menampilkan nilai Alpha Cronbach variabel $X_{1}$ sebesar 0,790, nilai tersebut berada pada rentang 0,70 sampai 0,90, maka dapat dikatakan reliabilitas terpenuhi dengan reliabilitas yang tinggi. Nilai Alpha Cronbach variabel $\mathrm{X}_{2}$ sebesar 0,598, reliabel moderat. Nilai Alpha Cronbach variabel Y sebesar 0,737 , dinyatakan reliabilitas tinggi.

\section{Hasil Penelitian dan Pembahasan}

\section{Uji Asumsi Klasik}

Pengujian asumsi klasik dilakukan dengan uji Normalitas Regresi, Multikolinearitas, Heteroskedastisitas, dan Autokorelasi. Uji normalitas pada model regresi digunakan untuk menguji apakah nilai residual yang dihasilkan dari regresi terdistribusi secara normal atau tidak. Model regresi yang baik adalah yang memiliki nilai residual yang terdistribusi secara normal. Uji Normalitas Regresi dilakukan dengan metode One Sample Kolmogorov Smirnov. Residual berdistribusi normal jika nilai signifikansi lebih dari 0,05.

Tabel 3. Uji Normalitas Regresi

\begin{tabular}{|c|c|c|}
\hline & & $\begin{array}{c}\text { Unstandardized } \\
\text { Residual }\end{array}$ \\
\hline \multicolumn{2}{|l|}{$\mathrm{N}$} & 89 \\
\hline \multirow[t]{2}{*}{ Normal Parameters $(a, b)$} & Mean & 0000000 \\
\hline & Std. Deviation & 2,55523187 \\
\hline \multirow[t]{3}{*}{ Most Extreme Differences } & Absolute & 100 \\
\hline & Positive & 061 \\
\hline & Negative &,- 100 \\
\hline \multicolumn{2}{|l|}{ Kolmogorov-Smirnov Z } & ,943 \\
\hline \multicolumn{2}{|l|}{ Asymp. Sig. (2-tailed) } & ,336 \\
\hline
\end{tabular}

Tabel 3. menampilkan nilai signifikansi (Asymp.Sig 2-tailed) sebesar 0,336. Karena signifikansi lebih dari 0,05 $(0,336>0,05)$, maka nilai residual tersebut berdistribusi normal.

Uji Heteroskedastisitas digunakan untuk mengetahui adanya ketidaksamaan varian dari residual untuk semua pengamatan pada model regresi. Prasyarat yang harus terpenuhi dalam model regresi adalah tidak adanya gejala heteroskedastisitas. Pengujian dilakukan dengan uji Glejser, 
jika nilai signifikansi antara variabel independen dengan absolut residual lebih dari 0,05 maka tidak terjadi masalah heteroskedastisitas.

Tabel 4. Uji Heteroskedastisitas Model Regresi

\begin{tabular}{|c|c|c|c|c|c|c|}
\hline \multirow[t]{2}{*}{ Model } & & \multicolumn{2}{|c|}{ Unstandardized Coefficients } & \multirow{2}{*}{$\begin{array}{c}\text { Standardized Coefficients } \\
\text { Beta } \\
\end{array}$} & \multirow{2}{*}{$\mathrm{t}$} & \multirow{2}{*}{$\begin{array}{l}\text { Sig. } \\
\text { Std. } \\
\text { Error }\end{array}$} \\
\hline & & B & Std. Error & & & \\
\hline 1 & (Constant) & 2,198 & 1,456 & & $\begin{array}{r}1,51 \\
0\end{array}$ &, 135 \\
\hline & pelayanan &,- 013 &, 076 &,- 029 & $16 \overline{-}$ & 868 \\
\hline & fasilitas &, 057 &, 085 &, 128 & 674 &, 502 \\
\hline & kepuasan_mahasiswa &,- 045 &, 072 &,- 129 & , 618 &, 539 \\
\hline
\end{tabular}

Dari output di atas dapat diketahui bahwa nilai signifikansi ketiga variabel independen lebih dari 0,05. Dengan demikian dapat disimpulkan bahwa tidak terjadi masalah heteroskedastisitas pada model regresi.

Uji multikolinearitas digunakan untuk mengetahui ada atau tidaknya penyimpangan asumsi klasik multikolinearitas, yaitu adanya hubungan linear antar variabel independen dalam model regresi. Prasyarat yang harus terpenuhi dalam model regresi adalah tidak adanya multikolinearitas. Pengujian ada tidaknya gejala multikolinearitas dilakukan dengan melihat nilai VIF (Variance Inflation Factor) dan Tolerance. Apabila nilai VIF berada dibawah 10,00 dan nilai Tolerance lebih dari 0,100, maka diambil kesimpulan bahwa model regresi tersebut tidak terdapat masalah multikolinearitas.

Tabel 5. Uji Multikolinearitas

\begin{tabular}{|c|c|c|c|c|c|c|c|c|}
\hline \multirow[b]{2}{*}{ Mode } & & \multicolumn{2}{|c|}{$\begin{array}{l}\text { Unstandardized } \\
\text { Coefficients }\end{array}$} & \multirow{2}{*}{$\begin{array}{c}\begin{array}{c}\text { Standardized } \\
\text { Coefficients }\end{array} \\
\text { Beta } \\
\end{array}$} & \multirow{2}{*}{$\begin{array}{c}\mathrm{t} \\
\text { Tolerance }\end{array}$} & \multirow{2}{*}{$\begin{array}{l}\text { Sig. } \\
\text { VIF }\end{array}$} & \multicolumn{2}{|c|}{ Collinearity Statistics } \\
\hline & & B & Std. Error & & & & B & Std. Error \\
\hline 1 & (Constant) & -.225 & 2,170 & &,- 104 & ,918 & & \\
\hline & pelayanan & ,495 &, 099 & 393 & 4,993 &, 000 & , 499 & 2,002 \\
\hline & fasilitas & ,691 & 102 & ,533 & 6,779 &, 000 & ,499 & 2,002 \\
\hline
\end{tabular}

Tabel 5. menampilkan nilai Variance Inflation Factor (VIF) kedua variabel yaitu $X_{1}$ dan $X_{2}$ adalah 2,002 lebih kecil dari 10 dan Tolerance lebih dari 0,100, sehingga antar variabel independen tidak terjadi multikolinearitas.

Uji Autokorelasi digunakan untuk mengetahui ada atau tidaknya penyimpangan asumsi klasik autokorelasi, yaitu korelasi yang terjadi antara residual pada satu pengamatan dengan pengamatan lain pada model regresi. Prasyarat yang harus terpenuhi adalah tidak adanya autokorelasi dalam model regresi. Metode pengujian yang sering digunakan adalah dengan uji Durbin-Watson (uji DW). 
Tabel 6. Uji Autokorelasi

\begin{tabular}{|l|c|r|r|r|r|}
\hline Model & R & R Square & $\begin{array}{c}\text { Adjusted R } \\
\text { Square }\end{array}$ & $\begin{array}{c}\text { Std. Error of } \\
\text { the Estimate }\end{array}$ & Durbin-Watson \\
\hline 1 &, $857(a)$ &, 734 &, 728 & 2,585 & 1,676 \\
\hline
\end{tabular}
a Predictors: (Constant), fasilitas, pelayanan
b Dependent Variable: kepuasan_mahasiswa

Tabel 6. menampilkan nilai DW yang dihasilkan dari model regresi adalah 1,676. Sedangkan dari tabel DW dengan signifikansi 0,05 dan jumlah data=89, dengan $\mathrm{k}=2$ diperoleh nilai $\mathrm{dL}$ sebesar 1,609 dan dU sebesar 1,701. Karena nilai DW berada pada daerah antara dL dan dU, maka tidak menghasilkan kesimpulan yang pasti.

\section{Uji Hipotesis Penelitian}

Regresi Linier Berganda adalah hubungan secara linear antara dua atau lebih variabel independen $\left(\mathrm{X}_{1}, \mathrm{X}_{2}, \ldots . \mathrm{Xn}\right)$ dengan variabel dependen $(\mathrm{Y})$. Analisis Regresi Linier Berganda digunakan untuk mengetahui pengaruh antara variabel independen $\left(\mathrm{X}_{1}, \mathrm{X}_{2}, \ldots \mathrm{Xn}\right)$ terhadap variabel dependen. Persamaan regresi linear berganda sebagai berikut:

$\mathrm{Y}^{\prime}=\mathrm{a}+\mathrm{b}_{1} \mathrm{X}_{1}+\mathrm{b}_{2} \mathrm{X}_{2}+\ldots+\mathrm{bnXn}$

Keterangan:

$$
\begin{array}{ll}
\mathrm{Y}^{\prime} & : \text { Variabel dependen } \\
\mathrm{X}_{1} \& \mathrm{X}_{2} & \text { : Variabel independen } \\
\mathrm{A} & : \text { Konstanta (nilai } \mathrm{Y}^{\prime} \text { apabila } \mathrm{X}_{1}, \mathrm{X}_{2} \ldots . . \mathrm{Xn}=0 \text { ) } \\
\mathrm{B} & \begin{array}{c}
\text { Koefisien regresi (nilai peningkatan ataupun } \\
\text { penurunan) }
\end{array}
\end{array}
$$

\begin{tabular}{|c|c|c|c|c|c|c|}
\hline \multirow[b]{2}{*}{ Model } & & \multicolumn{2}{|c|}{$\begin{array}{c}\text { Unstandardized } \\
\text { Coefficients }\end{array}$} & \multirow{2}{*}{$\begin{array}{c}\begin{array}{c}\text { Standardized } \\
\text { Coefficients }\end{array} \\
\text { Beta } \\
\end{array}$} & \multirow{2}{*}{$\mathrm{t}$} & \multirow{2}{*}{$\begin{array}{c}\text { Sig. } \\
\text { Std. Error }\end{array}$} \\
\hline & & B & Std. Error & & & \\
\hline \multirow[t]{3}{*}{1} & (Constant) &,- 225 & 2,170 & &,- 104 &, 918 \\
\hline & pelayanan &, 495 &, 099 & ,393 & 4,993 &, 000 \\
\hline & fasilitas & 691 & , 102 &, 533 & 6,779 &, 000 \\
\hline
\end{tabular}

Tabel 7. Analisis Regresi Linier Berganda

Tabel 7. menampilkan hasil analisis Regresi Linier Berganda dengan persamaan sebagai berikut:

$Y^{\prime}=(-0,225)+0,495 X_{1}+0,691 X_{2}$

Konstanta $-0,225$ menyatakan jika Pelayanan $\left(X_{1}\right)$ dan Fasilitas $\left(X_{2}\right)$ bernilai 0, maka Kepuasan Mahasiswa $(Y)$ bernilai -0,225. Koefisien regresi variabel $X_{1}$ sebesar 0,495 menyatakan jika variabel independen lain bernilai tetap dan Pelayanan mengalami kenaikan 1\%, maka Kepuasan Mahasiswa akan mengalami kenaikan sebesar 0,495. Koefisien regresi variabel $\mathrm{X}_{2}$ sebesar 0,691 menyatakan jika variabel independen 
lain nilainya tetap dan Fasilitas mengalami kenaikan 1\%, maka Kepuasan Mahasiswa akan mengalami peningkatan sebesar 0,691.

Koefisien Pelayanan dan Fasilitas bernilai positif artinya terjadi hubungan positif antara Pelayanan dan Fasilitas terhadap Kepuasan Mahasiswa STABN Sriwijaya. Kenaikan Pelayanan dan Fasilitas akan diikuti dengan peningkatan Kepuasan Mahasiswa STABN Sriwijaya. Penurunan Pelayanan dan Fasilitas akan diikuti dengan menurunnya tingkat kepuasan Mahasiswa STABN Sriwijaya.

Analisis Determinasi dalam Regresi Linear Berganda digunakan untuk mengetahui sumbangan pengaruh variabel independen secara bersamasama terhadap variabel dependen.

Tabel 8. Model Summary Analisis Determinansi

\begin{tabular}{l|r|r|r|r|}
\hline Model & $\mathrm{R}$ & R Square & $\begin{array}{c}\text { Adjusted R } \\
\text { Square }\end{array}$ & $\begin{array}{c}\text { Std. Error of } \\
\text { the Estimate }\end{array}$ \\
\hline 1 &, $857(\mathrm{a})$ &, 734 &, 728 & 2,585 \\
\hline
\end{tabular}
$\begin{aligned} & \text { a Predictors: (Constant), fasilitas, pelayanan } \\
& \text { b Dependent Variable: kepuasan_mahasiswa }\end{aligned}$

Tabel 8. menampilkan angka R2 ( $R$ Square) sebesar 0,734 atau (73,4\%), menyatakan sumbangan pengaruh Pelayanan dan Fasilitas terhadap Kepuasan Mahasiswa STABN Sriwijaya sebesar 73, 4\%. 26,6\% dipengaruhi variabel lain yang tidak dijelaskan dalam penelitian ini.

Uji Koefisien Regresi digunakan untuk mengetahui apakah variabel independen secara bersama-sama berpengaruh signifikan terhadap variabel dependen, atau untuk mengetahui apakah model regresi dapat digunakan untuk memprediksi variabel dependen. Signifikansi menyatakan hubungan yang terjadi dapat digeneralisasikan untuk seluruh populasi. Hipotesis yang diajukan adalah:

Ho: Tidak ada pengaruh signifikan antara Pelayanan dan Fasilitas secara bersama-sama terhadap Kepuasan Mahasiswa STABN Sriwijaya.

Ha : Ada pengaruh signifikan antara Pelayanan dan Fasilitas secara antara terhadap Kepuasan Mahasiswa STABN Sriwijaya.

Kriteria pengujian:

- Ho diterima bila F hitung < F tabel

- Ho ditolak bila F hitung > F tabel 
Tabel 9. Koefisien Regresi

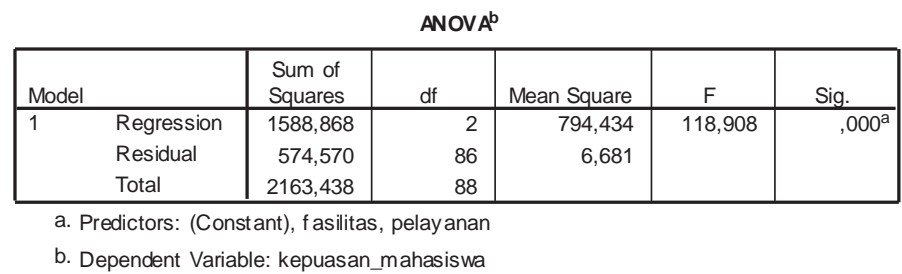

Dengan tingkat signifikansi 95\%, a=5\%, didapatkan $\mathrm{F}$ tabel sebesar 3,10. Membandingkan F hitung dengan F tabel, nilai F hitung $(3,10)>$ F tabel $(118,90)$, maka Ho ditolak. Artinya ada pengaruh signifikan antara Pelayanan dan Fasilitas secara bersama-sama terhadap Kepuasan Mahasiswa STABN Sriwijaya. Dapat disimpulkan bahwa Pelayanan dan Fasilitas secara bersama-sama berpengaruh terhadap Kepuasan Mahasiswa STABN Sriwijaya.

Uji Koefisien Regresi Parsial digunakan untuk mengetahui apakah dalam model regresi variabel independen secara parsial (terpisah) berpengaruh signifikan terhadap variabel dependen. Hipotesis yang diajukan untuk variabel Pelayanan:

Ho : Secara parsial tidak ada pengaruh signifikan antara Pelayanan dengan Kepuasan Mahasiswa STABN Sriwijaya

Ha : Secara parsial ada pengaruh signifikan antara Pelayanan dengan Kepuasan Mahasiswa STABN Sriwijaya

Tabel 10. Uji Koefisien Regresi Parsial

\begin{tabular}{|c|c|c|c|c|c|c|}
\hline \multicolumn{7}{|c|}{ Coeffi cients $^{a}$} \\
\hline & & \multicolumn{2}{|c|}{$\begin{array}{l}\text { Unstandardized } \\
\text { Coefficients }\end{array}$} & $\begin{array}{l}\text { Standardized } \\
\text { Coeff icients }\end{array}$ & & \\
\hline \multicolumn{2}{|c|}{ Model } & $\mathrm{B}$ & Std. Error & Beta & $\mathrm{t}$ & Sig. \\
\hline \multirow[t]{3}{*}{1} & (Constant) &,- 225 & 2,170 & &,- 104 & ,918 \\
\hline & pelayanan &, 495 & ,099 & ,393 & 4,993 &, 000 \\
\hline & f asilitas & ,691 & ,102 &, 533 & 6,779 & ,000 \\
\hline
\end{tabular}

a. Dependent Variable: kepuasan_mahasiswa

Kriteria pengujian:

- Ho diterima bila $<\mathrm{t}$ hitung $<\mathrm{t}$ tabel

- Ho ditolak bila $t$ hitung $>\mathrm{t}$ tabel

Dengan tingkat signifikansi $a=5 \%$, didapatkan $t$ hitung untuk variabel Pelayanan sebesar 4,993 dan t hitung untuk variabel Fasilitas sebesar 6,779 . Dengan pengujian dua sisi (signifikansi=0,025), maka diperoleh $t$ tabel sebesar 1,987. Membandingkan $t$ hitung dengan $t$ tabel, untuk variabel Pelayanan (4,993 >1,987), maka Ho ditolak. Ha diterima menyatakan secara parsial ada pengaruh signifikan antara Pelayanan dengan Kepuasan Mahasiswa STABN Sriwijaya. 
Untuk variabel Fasilitas, hipotesis yang diajukan:

Ho: Secara parsial tidak ada pengaruh signifikan antara Fasilitas dengan Kepuasan Mahasiswa STABN Sriwijaya

Ha: Secara parsial ada pengaruh signifikan antara Fasilitas dengan Kepuasan Mahasiswa STABN Sriwijaya

Kriteria pengujian:

- Ho diterima bila $\mathrm{t}$ hitung $<\mathrm{t}$ tabel

- Ho ditolak bila $t$ hitung $>\mathrm{t}$ tabel

t hitung untuk variabel Fasilitas sebesar 6,779 $(6,779>1,987)$, maka Ho ditolak. Ha diterima artinya secara parsial ada pengaruh signifikan antara Fasilitas dengan Kepuasan Mahasiswa STABN Sriwijaya.

\section{E. Kesimpulan}

Persamaan Regresi Linier Berganda $Y^{\prime}=(-0,225)+0,495 X_{1}+0,691 X_{2}$. Konstanta sebesar -0,225 menyatakan jika Pelayanan dan Fasilitas bernilai 0, maka Kepuasan Mahasiswa bernilai -0,225. Koefisien regresi variabel Pelayanan sebesar 0,495 menyatakan jika variabel independen lain bernilai tetap dan Pelayanan mengalami kenaikan 1\%, maka Kepuasan Mahasiswa akan mengalami kenaikan sebesar 0,495. Koefisien regresi variabel Fasilitas sebesar 0,691 menyatakan jika variabel independen lain nilainya tetap dan Fasilitas mengalami kenaikan 1\%, maka Kepuasan Mahasiswa akan mengalami peningkatan sebesar 0,691. Koefisien Pelayanan dan Fasilitas bernilai positif artinya terjadi hubungan positif antara Pelayanan dan Fasilitas terhadap Kepuasan Mahasiswa STABN Sriwijaya. Kenaikan Pelayanan dan Fasilitas akan diikuti dengan peningkatan Kepuasan Mahasiswa STABN Sriwijaya. Penurunan Pelayanan dan Fasilitas akan diikuti dengan menurunnya tingkat kepuasan Mahasiswa STABN Sriwijaya.

Ada pengaruh signifikan antara Pelayanan dan Fasilitas secara bersama-sama terhadap Kepuasan Mahasiswa STABN Sriwijaya. Pengaruh Pelayanan dan Fasilitas terhadap Kepuasan Mahasiswa sebesar 73,4\%, 26,6\% dipengaruhi variabel lain yang tidak dijelaskan dalam penelitian. Secara parsial ada pengaruh signifikan antara Pelayanan terhadap Kepuasan Mahasiswa STABN Sriwijaya dan secara parsial ada pengaruh signifikan antara Fasilitas dengan Kepuasan Mahasiswa STABN Sriwijaya. 


\section{Daftar Pustaka}

Abdullah, Sukirno, Annisa, dkk. 2013. Analisis Kualitas Pelayanan terhadap Kepuasan Mahasiswa pada Fakultas Ekonomi Universitas Negeri Yogyakarta. Jurnal Nominal. Fakultas Ekonomi Universitas Negeri Yogyakarta, Volume II Nomor I.

Ayu, Gusti. 2010. Faktor-Faktor Penentu Kepuasan Mahasiswa Terhadap Pelayanan Fakultas Sebagai Lembaga Pendidikan. Fakultas FMIPA. Universitas Udayana.

Furqon, Chairul. 2008. Kualitas Pelayanan Pada Perguruan Tinggi. Jurnal Ilmu Administrasi Volume IV, No. 4. Program Studi Manajemen, Universitas Pendidikan Indonesia Bandung.

Rinala, Yudana, Natajaya. 2013. Pengaruh Kualitas Pelayanan Akademik Terhadap Kepuasan Dan Loyalitas Mahasiswa Pada Sekolah Tinggi Pariwisata Nusa Dua Bali. E-Journal, volume 4. Program Pascasarjana Universitas Pendidikan Ganesha Program Studi Administrasi Pendidikan.

Kotler, Armstrong. 2014. Principles of Marketing, Global Edition. Pearson, England.

Kotler, Keller. 2009. Manajemen Pemasaran. Cetakan Pertama, Graha Ilmu, Yogyakarta.

Kotler, Keller. 2012. Marketing Management 14th. Prentice Hall, Newyork.

Nugraha, Reni Amaranti. 2012. Analisis Pengukuran Kepuasan Mahasiswa Terhadap Kualitas Layanan Akademik di Perguruan Tinggi. Prosiding SnaPP2012, Sains, Teknologi, dan Kesehatan, ISSN: 2089-3582.

Nugroho, Wahyu. 2011. Riset Pemasaran dan Konsumen. IPB Press, Bogor.

Puja Subekti. 2014. Pengaruh Gaya Kepemimpinan Ketua, Kompetensi Dosen, dan Kualitas Pelayanan Administrasi terhadap Kepuasan Mahasiswa di Sekolah Tinggi Agama Buddha Negeri Sriwijaya Tangerang Banten. Tesis. Program Pascasarjana Universitas Budi Luhur.

Rangkuti, Fredy. 2011. Riset Pemasaran. Gramedia, Jakarta.

Ratnasari, Ririn Tri dan Mastuti. 2011. Manajemen Pemasaran. Ghalis Indonesia, Bogor.

Sugiyono. 2012. Metode Penelitian Kuantitatif, Kualitatif dan R\&D. Alfabeta, Bandung. 
. 2013. Metode Penelitian Pendidikan (Pendekatan Kuantitatif, Kualitatif, dan R\&D). Bandung: Alfabeta.

Tjiptono, Fandy. 2009. Service management. Penerbit ANDI, Yogyakarta.

Uyanto, Stanislaus. 2009. Pedoman Analisis Data dengan SPSS. Edisi 3, Graha Ilmu, Yogyakarta.

Waluyo. 2010. Tingkat Kepuasan Mahasiswa Stabn Sriwijaya Terhadap Kualitas Layanan Akademik Tahun 2010. Jurusan Dharmacarya, Sekolah Tinggi Agama Buddha Negeri Sriwijaya Tangerang Banten.

Yamit, Zulian. 2010. Manajemen Kualitas Produk dan Jasa. Ekonisia, Yogyakarta. 